\title{
POŠTA
}

TELEKOMUNIKÁCIE A

ELEKTRONICKY OBCHOD

Qlelentoming

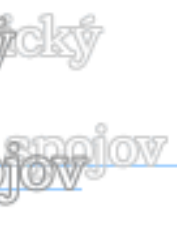

\section{ZÁSAHY ŠTÁTU V OBLASTI POLITIKY HOSPODÁRSKEJ SÚŤAŽE}

\section{Lucia Madleňáková*}

Efektívna hospodárska sút’až predstavuje základ ekonomiky vol'ného trhu. Znižuje ceny, zvyšuje kvalitu, poskytuje spotrebitel'ovi možnost' lepšieho výberu a umožňuje rozvoj technologických inovácií. Predstavuje súbor určitých pravidiel správania sa podnikatel'ov a štátu na trhu, ktorých dodržiavanie je predpokladom d’alšieho hospodárskeho rozvoja $\mathrm{v}$ prospech samotných spotrebitel'ov i celej spoločnosti. Funguje efektívne, ak podnikatelia pôsobiaci na trhu môžu robit' svoje obchodné rozhodnutia samostatne. Ide o nástroj na riešenie trhových zlyhaní, ktoré vyplývajú z nedostatku konkurencie.

Každý účastník trhu, ktorý chce obstát' v konkurencii, je na jednej strane nútený naplńă' funkcie hospodárskej sút'aže a tým prispievat' k efektívnosti spoločnosti, na druhej strane si každý podnikatel' uvedomuje, že jedna z ciest ako eliminovat' riziko neúspechu na trhu a porazit' svojich konkurentov je použit' stratégiu, ktorá narúša pravé konkurenčné prostredie a vedie k obmedzovaniu hospodárskej sút’aže.

Podl'a právnej úpravy v SR je obmedzovaním sút'aže každé obmedzenie vol'nosti konania podnikatel'a na relevantnom trhu, najmä vylučovanie existujúcich alebo možných sút’ažných aktivít, skutočné alebo možné zníženie rozsahu konkurenčnej aktivity alebo skresl’ovanie konkurenčných podmienok. Štát stanovuje presné pravidlá hospodárskej sút'aže a zároveň dbá o ich dodržiavanie a sankcionuje všetkých tých, ktorí tieto pravidlá porušujú. Ciel'om politiky hospodárskej sút’aže je najmä dosiahnutie efektívnosti na trhu. [7]

Korekcie, ktoré v tejto oblasti vykonáva Protimonopolný úrad, vychádzajú z jemu zverených kompetencií určených zákonom č. 136/2001 Z. z. o ochrane hospodárskej sút’aže.

Sloboda podnikatel'ského rozhodovania zahŕňa aj právo podnikatel'a prirodzene prispôsobovat' svoje správanie trhovému prostrediu. Predpokladom efektívnej hospodárskej sút’aže je preto vylúčenie akýchkol'vek kontaktov medzi konkurentmi s ciel'om ovplyvnit' správanie svojho konkurenta, a to či už skutočného, alebo len potenciálneho. Rovnako je potrebné vylúčit', aby podnikatelia odhal'ovali svojim konkurentom vlastné podnikatel'ské zámery. [2]

Prax však dokázala, že dokonalý stav hospodárskej sút’aže je skôr teóriou ako praxou. Preto sa EÚ rozhodla vytvorit' systém pravidiel na fungovanie efektívnej hospodárskej sút'aže a takto ju chránit' pred obmedzovaním neodôvodnenými zásahmi členských štátov a nesút’ažným správaním sa samotných podnikov.

Strážcom hospodárskej sút’aže $\mathrm{v}$ EÚ je Európska komisia, ktorá disponuje značným rozsahom nástrojov. Ide najmä o zákaz kartelov na jednotnom trhu, zákaz zneužívania dominantného postavenia na trhu, zabezpečenie rovnoprávneho postavenia a rovnakého

\footnotetext{
* Ing. Lucia Madleňáková, PhD., Žilinská univerzita v Žiline, Fakulata Prevádzky a ekonomiky dopravy a spojov, Katedra spojov, Univerzitná 1, 01026 Žilina tel.: $+421 / 41 / 4133125$, fax: $+421 / 41 / 5655615$

e-mail: Lucia.Madlenakova@fpedas.utc.sk
} 
prístupu $\mathrm{k}$ verejným a súkromným podnikom, kontrolu fúzií a dohl'ad nad národnými subvenciami či štátnou pomocou.

Ochrana hospodárskej sút'aže sa dotýka podnikatel'ských subjektov $\mathrm{v}$ dvoch základných oblastiach a to:

- V oblasti protisút'ažného správania sa podnikov (tzv. protimonopolná resp. antitrustová politika),

- v oblasti štátnej intervencie, ktorá môže deformovat' sút’až predovšetkým prostredníctvom poskytovania štátnej pomoci.

V súčasnosti je právna úprava vel'mi striktná bez ohl'adu na to, či je porušovatel'om sút’aže súkromná osoba alebo štát. Týka sa to napr. zákazu diskriminácie zo strany štátnych monopolov komerčnej povahy, zákazu takých dohôd a postupov podnikov, ktoré odporujú pravidlám hospodárskej sútaže, zneužívania dominantného postavenia na trhu, podmienok na udel'ovanie štátnych podpôr a pod.

Výnimky sú stanovené len za presne vymedzených podmienok, napríklad s vnútorným trhom EÚ je zlučitel'ná:

- podpora sociálnej povahy poskytovaná individuálnym spotrebitel'om,

- podpora určená na náhradu škody spôsobenej prírodnými katastrofami a mimoriadnymi udalost'ami,

- podpora na pomoc hospodárskemu rozvoju oblastí s mimoriadne nízkou životnou úrovňou alebo s mimoriadne vysokou nezamestnanost'ou.

Za porušenie sút'aže však možno označit' aj praktiky subjektov so sídlom v tret'om štáte, ak môžu ovplyvnit' obchodnú činnost' medzi členskými štátmi, zabránit', obmedzit' alebo priamo narušit' sút’až, prípadne zneužit' dominantné postavenie na vnútornom trhu EÚ.

\begin{tabular}{|l|ll|}
\hline \multicolumn{1}{|c|}{ Prínosy } & \multicolumn{1}{c|}{ Riziká } \\
\hline - $\begin{array}{l}\text { stanovenie jasných pravidiel pri ochrane } \\
\text { hospodárskej sút'aže } \\
\text { zjednodušenie podnikania v rámci } \\
\text { jednotného trhu EÚ } \\
\text { využitie komparatívnych výhod pri } \\
\begin{array}{l}\text { získavaní nových trhov v rámci } \\
\text { jednotného trhu EÚ } \\
\text { poskytovanie štátnej pomoci v rámci } \\
\text { pravidiel EÚ }\end{array}\end{array}$ & $\begin{array}{l}\text { tlak na zvýšenie konkurencie schopnosti } \\
\text { slovenských výrobcov } \\
\text { tlak na podnikatel'ov pri hl'adaní } \\
\text { vnútorných rezerv s ohl'adom na } \\
\text { efektívnu alokáciu zdrojov } \\
\text { prísnejší postih za porušovanie pravidiel } \\
\text { hospodárskej sút'aže (v kompetencii }\end{array}$ \\
\hline
\end{tabular}

Obrázok 1 Prínosy a riziká hospodárskej sút’aže

\section{Protimonopolná politika - sút’ažné právo}

Vytvorenie vnútorného trhu v rámci EÚ predpokladá stanovenie jasných a jednotných pravidiel pre podnikanie s ciel'om zamedzit':

- dohodám obmedzujúcim sút’až, ako sú napríklad dohody o cenách tovaru alebo služieb;

- zneužívaniu dominantného postavenia na trhu;

- nežiaducim koncentráciám;

- podpore vlastného priemyslu zamedzením dovozu výrobkov z iného členského štátu EÚ. [1]

Právny rámec sút'ažného práva na Slovensku tvorí predovšetkým zákon o ochrane hospodárskej sútaže, ktorý je kompatibilný s právnou úpravou platnou v EÚ. Zákon zakazuje akékol'vek dohody alebo zosúladené postupy podnikatel'ov, ako aj rozhodnutia združení podnikatel'ov, ktorých ciel'om alebo následkom môže byt' obmedzovanie sút’aže najmä 
z pohl'adu cien, obmedzenia alebo kontroly objemu výroby či rozdelenia trhu, alebo zdrojov zásobovania a pod. Nemusí íst' len o písomné dohody, ale aj nezáväzné dohovory typu „džentlmenských“ dohôd. [1]

Pokial' ide o skupinové (blokové) výnimky, na Slovensku bol prijatý zákon č. 465/2002 Z. z. o skupinových výnimkách zo zákazu dohôd obmedzujúcich hospodársku sút’až, ktorým sa kompletizuje právna úprava antitrustu u nás. Právna úprava na rozdiel od dohôd obmedzujúcich sút'až nezakazuje samotnú existenciu dominantného postavenia na trhu, ale len jeho zneužívanie. Správanie subjektov sa posudzuje na určitom vymedzenom, tzv. relevantnom trhu.

V praxi sú bežne známe tendencie podnikov zväčšovat' svoju ekonomickú moc a konkurencieschopnost' na jednej strane, čo môže vytvorit' podmienky a priestor na ich následné zneužívanie. Čo sa týka opatrení zameraných na kontrolu koncentrácie, príslušný orgán môže koncentráciu schválit' úplne, s určitými podmienkami, alebo ju zakázat'. V súlade so zákonom o ochrane hospodárskej sút’aže sa zakáže taká koncentrácia, ktorá vytvára alebo posilňuje dominantné postavenie na trhu, až kým účastníci nepreukážu, že túto ujmu na hospodárskej sút’aži prevážia celohospodárske výhody danej koncentrácie.

Ak dôjde ku koncentrácii, ktorá bude mat' vplyv na celé spoločenstvo, a teda aj na SR, alebo bude mat' komunitárnu dimenziu, t. j. bude spĺn̆at' kritériá stanovené v komunitárnom práve, takáto koncentrácia bude oznamovaná iba Európskej komisii, ktorá má v takýchto prípadoch výlučnú právomoc konat', a koncentráciu teda nebude musiet' schval'ovat' Protimonopolný úrad SR.

\section{Politika hospodárskej sút’aže}

Politika hospodárskej sút’aže EÚ hrá dôležitú úlohu pri dosahovaní ciel’ov konkurencieschopnosti vytýčené v lisabonskej stratégii. Zahŕňa nielen antitrustové pravidlá a pravidlá fúzií, ale aj uplatňovanie efektívnej a pevnej disciplíny štátnej pomoci. [6]

Politika hospodárskej sút'aže môže významne prispiet' k vytvoreniu podmienok, ktoré sú priaznivé na podnikanie. Pravidlá štátnej pomoci zohrávajú dôležitú úlohu $\mathrm{v}$ úsilí o zvýšenie dostupnosti rizikového kapitálu pre začínajúcich podnikatel'ov i pre malé a stredné podniky. Politika medzinárodnej hospodárskej sút'aže pomáha rozvíjat' aj celosvetovú súdržnost' a predpovedatel'nost', ktoré podnikanie potrebuje. Napokon, zásady hospodárskej sút’aže umožnia podrobné skúmanie nových a jestvujúcich regulačných rámcov $\mathrm{v}$ iných dôležitých oblastiach politiky s ciel'om zabezpečit', aby regulovanie zbytočne neobmedzovalo hospodársku sút'až. Obhajovanie hospodárskej sút’aže môže teda pomôct' pri formovaní regulačného rámca Európskej únie a vnútroštátnych regulačných rámcov v záujme podpory režimu priaznivého pre hospodársku sút’až a konkurencieschopnost'. [4]

\section{Ďalšie princípy fungovania hospodárskej sút’aže}

Medzi d'alšie dôležité princípy fungovania hospodárskej sút'aže patrí:

- liberalizácia monopolov,

- úprava poskytovania štátnej pomoci v zmysle pravidiel EÚ.

\section{Štátna pomoc}

Súčast'ou riešenia problematiky ochrany hospodárskej sút'aže je aj poskytovanie štátnej podpory zo štátnych, resp. verejných prostriedkov, ktoré narúšajú alebo hrozia narušením sút'aže tým, že zvýhodňujú určité podniky alebo určité odvetvia výroby.

Kontrola štátnej pomoci sa zameriava na vplyvy opatrení pomoci udelenej členskými štátmi podnikom na hospodársku sút’až. 
Ciel': zabezpečit', aby vládne intervencie nezasahovali do hladkého fungovania vnútorného trhu, podporit' hospodársku sút’až a konkurenčné trhy a zlepšit' štrukturálne reformy. Mimoriadna pozornost' sa venuje zabezpečovaniu toho, aby prospešné vplyvy liberalizácie neboli podkopané opatreniami štátnej pomoci. [5]

Medzi najčastejšie prípady štátnych podpôr patria:

- daňové úl'avy,

- dotácie,

- oslobodenie od úrokov,

- výhodné pôžičky,

- výhody v oblasti sociálnych systémov,

- prevzatie záruk za vel'mi výhodných podmienok,

- bezplatné alebo vel'mi výhodné prenajímanie budov a pozemkov,

- výhodné podmienky na dodávky tovaru a pod.

Tak ako na jednej strane môže prispiet' poskytovanie štátnej pomoci k rozvoju, na druhej strane môže negatívne zasiahnut' a narušit' hospodársku sút’až. V tejto súvislosti EÚ pristúpila $\mathrm{k}$ úprave pravidiel pre kontrolu poskytovania štátnych podpôr a určeniu podmienok na jej poskytovanie. $V$ podmienkach SR bol prijatý zákon č. 231/1999 Z. z. o štátnej pomoci v znení neskorších predpisov, ktorý po novelizáciách dosiahol plnú kompatibilitu $\mathrm{s}$ právom EÚ. [8]

\section{Štátna pomoc a služby všeobecného záujmu}

Významnou sa stáva aj otázka stanovenia optimálneho vzt’ahu medzi štátnou pomocou a službami všeobecného záujmu. Charakter stanovených podmienok si vyžaduje zvýšenie právnej istoty, hlavne v oblasti odhadu nákladov, definovania spôsobu financovania služieb a popisu záväzkov verejnej služby s nárokom na kompenzáciu. Zelená kniha o službách všeobecného záujmu, uverejnená v máji 2003, potvrdila potrebu zvážit', či princípy, ktorými sa riadi poskytovanie služieb všeobecného záujmu, by mali byt' d’alej upravené vo všeobecnom komunitárnom rámci, vrátane definovania optimálnych pravidiel pre služby a opatrenia, aby sa zvýšila právna istota pre všetkých účastníkov trhu.

Tam, kde nie sú správne definované a financované, povinnosti univerzálnych služieb by mohli spôsobit', že spoločnosti s takýmito záväzkami budú vystavené narastajúcim stratám, vd'aka potenciálnemu vstupu konkurentov do najziskovejších oblastí svojej činnosti. [5]

Európsky hospodársky a sociálny výbor zdôraznil potrebu, už zvýraznenú $\mathrm{v}$ jeho stanovisku k Zelenej knihe Komisie, prijat' jasný právny text o službách všeobecného záujmu, aby sa zabezpečil efektívny a spravodlivý prístup pre všetkých používatel'ov $\mathrm{k}$ vysokokvalitným službám, ktoré spíňajú ich požiadavky. Okrem toho, odporúča čo možno najširšie podnecovanie dialógu so sociálnymi partnermi a mimovládnymi organizáciami, hlavne týkajúceho sa reorganizácie a fungovania sociálnych služieb. [5]

Ak by sme chceli konkretizovat' oblast' štátnej pomoci pri poskytovania služieb všeobecného záujmu, určite by sme sa nevyhli problematike regulácie poskytovania služieb v týchto odvetviach, ale najmä otázkam financovania univerzálnej služby v poštovom sektore a v prostredí elektronických komunikácií. Smernice EÚ často poskytujú návod na riešenie danej problematiky. V zmysle stanovených pravidiel jednotlivé členské krajiny prijali opatrenia na zabezpečenie tohto ciel'a.

V podmienkach SR bola prijatá smernica Európskeho parlamentu a Rady 2002/22/ES o univerzálnej službe a právach užívatel'ov týkajúcich sa elektronických komunikačných sieti a služieb (smernica o univerzálnej službe) a následne aj Vyhláška MDPT SR č. 501/2004 o zriad'ovaní a spravovaní osobitného účtu univerzálnej služby, kde sú jasne popísané pravidlá pre financovanie neprimeraného bremena pri poskytovaní univerzálnej služby. Pri riešení týchto problémov je voblasti elektronických komunikácií ul’ahčená situácia plne 
liberalizovaným trhom, problémy však ostávajú najmä v zneužívaní dominantného postavenia poskytovatel'a na jednotlivých relevantných trhoch, čím sa ohrozuje efektívna sút’až.

Iná je situácia v oblasti poskytovania poštových služieb, kde trh poštových služieb je liberalizovaný len čiastočne, to znamená, že dnes ešte funkciu kompenzácie neprimeraného finančného bremena z poskytovania univerzálnej služby supluje poskytovanie poštovej výhrady, t. j. služieb vyhradených len pre poskytovatel'a univerzálnej služby. Smernice Európskeho parlamentu a Rady 97/67/ES o spoločných pravidlách rozvoja vnútorného trhu poštových služieb Spoločenstva a zlepšovaní kvality služieb v znení smernice 2002/39/ES definuje podmienky poskytovania univerzálnej služby ale tiež možnosti zriadenia kompenzačného fondu za účelom krytia prípadných strát. Nakol’ko sa však blíži termín úplnej liberalizácie, na pôde Európskej komisie sa rieši otázka d’alších možnosti financovania neprimeraného finančného bremena, ked’že kompenzačný fond nezaznamenal $\mathrm{v}$ členských krajinách kladnú odozvu a k jeho zriadeniu a využitiu prakticky zatial' nedošlo. Rovnako tak možnost'ou je aj využitie krížového financovania. Pojem „križové dotácie“ znamená, že podnik znáša alebo pridelí všetky alebo čast' nákladov svojej činnosti, ktorú vykonáva v rámci jedného geografického trhu alebo trhu s výrobkami svojej činnosti na činnost' na inom geografickom trhu alebo trhu s výrobkami. Za určitých okolností by krížové dotácie $\mathrm{v}$ poštovom odvetví, kde takmer všetci poskytujú vyhradené alebo nevyhradené služby, mohli viest' $\mathrm{k}$ deformácii hospodárskej sút’aže a viest' k porážke konkurentov ponukami, ktoré sú možné nie vd’aka účinnosti (a úspor) a výkonom, ale krížovým dotáciám. Pre rozvoj poštového odvetvia je nevyhnutné vyvarovat' sa krížových dotácií, ktoré vedú k nespravodlivej hospodárskej sút’aži.

Krížové dotácie nedeformujú hospodársku sútaž, ked' na náklady na vyhradené činnosti sa poskytuje peňažná pomoc z príjmov, ktoré boli vytvorené inými vyhradenými službami, pretože pri týchto službách nie je možná hospodárska sútaž. Krížové dotácie medzi nevyhradenými činnost’ami nie sú samy o sebe nezákonné.

Avšak poskytovanie peňažnej pomoci na liberalizované služby tým, že ich náklady sa pridelia na vyhradené činnosti pravdepodobne povedie $\mathrm{k}$ deformácii hospodárskej sút’aže, pretože dôjde k porušeniu článku 86 . Mohlo by dôjst' až k zneužitiu zo strany podniku, ktorý má dominantné postavenie v rámci spoločenstva. Okrem toho uživatelia služieb, ktoré spadajú pod monopol, musia znášat' náklady, ktoré nesúvisia s poskytovaním týchto služieb. Napriek tomu aj dominantné spoločnosti majú právo konkurovat' v oblasti cien alebo zlepšit' svoje peňažné toky a získat' len čiastočný príspevok na svoje pevné (režijné) náklady, pokial' tieto ceny nebudú mat' zhubný účinok a nebudú znamenat' porušenie platných vnútroštátnych právnych predpisov alebo právnych predpisov spoločenstva. [3]

Práve riešenie problematiky financovania neprimeraného finančného bremena či krytia strát z poskytovania výkonov vo verejnom záujme si vyžaduje prijatie citlivých opatrení, nakol'ko výrazne zasahujú do pravidiel fungovania efektívnej sút’aže na trhoch prípadne vyvolávajú dojem porušovania pravidiel hospodárskej sút’aže zo strany štátu.

\section{Záver}

Presadzovanie hospodárskej sút'aže, ako aj jej obhajoba, môže prispiet' k lepšiemu fungovaniu vnútorného trhu, najmä v sektoroch, ktoré sú klúčovými pre lisabonskú agendu, pretože sa týkajú základných vstupov pre európsku ekonomiku. Otvorené a konkurencieschopné európske trhy urobia európske spoločnosti väčšmi medzinárodne konkurencieschopnými k prospechu európskych spotrebitel'ov a zamestnanosti v Európe. Dôsledné presadzovanie pravidiel hospodárskej sút'aže, ktoré má za ciel' odstránit' hlavné prekážky pre trhovú hospodársku sút’až, pomôže vytvorit' dobré podmienky pre rast. 


\section{Literatúra}

[1] FÍGEL, J., ADAMIŠ, M.: Slovensko na ceste do Európskej únie. Kapitoly a súvislosti. 2004. [online]. Bratislava: Zastúpenie Európskej komisie v SR, 2004. Dostupné na: http://www.europa.sk/test/content/sub_content/web-figel-complet.pdf

[2] Hospodárska sút’až. [online]. Dostupné na: http://www.euroinfo.gov.sk/index/go.php?id=1268\&idf=135\&lang=sk

[3] Oznámenie Komisie o používaní pravidiel sút’aže v odvetví pôšt a pri hodnotení niektorých štátnych opatrení týkajúcich sa poštových služieb (98/C 39/02). [online]. Dostupné na: http://europa.eu.int/eur-lex

[4] Správa o politike hospodárskej sút’aže za rok 2004. [online]. Brusel: Komisia Európskych Spoločenstiev, 17.6.2005. Dostupné na:

$<$ http://www.europarl.eu.int/meetdocs/2004_2009/documents/sec/com_sec(2005)0805_c om_sec(2005)0805 sk.pdf> - str: 6, 7

[5] Stanovisko Európskeho hospodárskeho a sociálneho výboru k „XXXIII. Správe o politike hospodárskej sút’ǎe - 2003”SEC(2004) 658 v konečnom znení. Dostupné na: http://europa.eu.int/eur-

[6] Úradný vestník Európskej únie (C222). [online]. Dostupné na: $<$ http://www.europa.eu.int/eur

[7] ŽIGOVÁ, S.: Ochrana hospodárskej sút’aže a vol’ný obchod v hutníckom priemysle vzhl'adom na vstup Slovenskej republiky do Európskej únie. [Autoreferát dizertačnej práce]. Ekonomická univerzita v Bratislave, Podnikovohospodárska fakulta v Košiciach, Košice, 2005.

[8] Živnostenské noviny, č. 6, ročník 3. [online]. November 2002., Dostupné na: $<$ http://www.szk.sk/noviny/ZN11_2002.pdf $>$

\section{Grantová podpora}

Bil/Nem/SR/ŽU/06 "Pravidla dodržiavania sút'aže na trhu elektronických komunikácií" 